\section{EXTRACTS FROM THE COURT ROLLS OF' THE CTTY OF NORWICH RELATING CHIEFLY TO INSTANCES OF STONE IN THE BLADDER.}

\section{By Charles Williams, F.R.C.S. EdiN.}

THE Court Rolls of the city of Norwich from about 1600 to 1690 afford conclusive evidence that in the Middle Ages stone in the bladder was by no means an unknown, or even an uncommon, disorder in that city. The complaint appears to have been as prevalent at that time as it has been since then, although its frequency has been much lessened of late years and is likely to be much more so in the future. In the fifteenth century no general hospitals were in existence in the provinces-except one at Canterbury and another at York-into which those who suffered from stone or any other disorder could be admitted, operated upon, and cared for until either a cure or death resulted. So far as Norwich is concerned there is abundant proof to show that those who were so afflicted were not allowed to die without surgical scelief being found for them, and it is my purpose to point out how that was carried out by giving from the Rolls such extracts as bear on the subject.

A certain routine was necessary to secure the services of an operator and to ensure his being paid for the operation and subsequent attendance. We may be perfectly certain that the poor in those times were quite unable to pay the expenses incidental to a large operation such as that must have been for stone in the bladder. The princioal mode of procedure was for the parent of the afflicted child, or the patient himself if he were old enough, to appear at the Guildhall before the mayor and court of aldermen and state the circumstances of the case before them. It was then ordered that the clergyman of the parish in which the sufferer lived should be directed to obtain the assent of the Lord Bishop to his preaching a sermon and making a collection on behalf of the case. This collection was to be handed to the mayor and aldermen by the swordbearer, or more generally by the aldermen of the ward in which the parish existed, and in whose hands the matter had been placed. A resolution was then passed directing how the sum of money so collected was to be dealt with. The following extracts from the rolls will show how that was effected. In some instances many parishes combined to make up the needful sum, and in some cases several Sundays were necessary, whilst in others a collection was made among the friends of the sufferer. The introduction of the Poor-law Act in 1711 completely altered the above mode of proceeding, indeed, did away with it, as will be noticed. In no instance is the particular kind of operation mentioned, the one in vogue was that known as the apparatus major. or the Marian method, so-called from Marianus, who first published an account of it in 1524. The operation, which was painful in its performance and very fatal in its consequences, was nevertheless considered to be more simple than the apparatus minor ${ }^{1}$ - which had been in use from the days of Celsus-and was quickly adopted and practised by all the best surgeons in Europe for nearly 200 years-i.e., until 1697; when the lateral was introduced in Paris as a new operation by Frère Jacques; this was improved by Cheselden in 1726 and soon superseded all others. In addition to those extracts which refer to cases of stone, I have added others which relate to medical matters, and which are both amusing and interesting.

The first entry relating to a case of stone is dated 35 Elizabeth, May 12th, 1593.

"This day Betterys Shieve, the wyfe of John Shieve of Tunstead and Elizabeth Sheringham wer deposed and sworn that John Hubbard of Norwich, surgeon, very artificyally did take from her a very greate stone that was in her bladder on Wednesday in Ester weke in anno 1593 without cutting, and that syns that time she had not been trobled with any payne of the stone."

It was also called "cutting on the gripe," because of cutting directly on the stone, fixed by the pressure of the fingers in the anus a knife and a hook being the only instrument used. The appellation of "apparatus minor" was given to it by Marianus to distinguish it from his method, which he named "apparatus major" on account of the multiplicity of instruments employed.
"14 James, 18 May (1616). - It is ordered that $\mathrm{Mr}$. Mayhew shall have IIII\& for cutting of Clere's child, and of one John Collins of the disease of the stone, whereof $20 s$. for Clere's child is to be paid by parish of St. Stephen, $20 s$. to be presently paid by parish of St. Andrew, and residue paid out of Hospitall upon perfecting the cure. 20s. more is appointed to be paid by the parish of St. Andrew, and yt ys ordered the same be equally paid and divided between two women who shall have the keeping of the said children."

"16 James, 16 May (1618). - Thomas, son of Thomas Mawson, is ordered to be cutt of the stone by Miles Mayhew, and he to have for the same $£ 3-\nabla i z ., 30 s$. in hand and $30 s$. when he shall be perfectly cured, if it so long live."

" 16 James, 21 Oct. (1618).-John Ebden, a child of the age of six years, son of Richard Fibden, is to be cutt and cured of the disease of the stone by Miles Mayhew, and he consenteth to take for the same such recompense as this court shall think fit to give him."

"1640, 23 Sept. - Ordered that £3 10s. be paid for cutting of John Terry, a poor child of St. George's parish, of the stone, and the doctor hath undertaken to doe the cure for $£ 3,30 s$. to be payd in hand and $30 s$. more to be payd him when the child is cured, and $10 \mathrm{~s}$, to be given to the poor child's mother to be layed out in necessaryes for him."

"1655, 27 Feb.-Overseers of St. Margaret laid out £3 $4 s$. for the charges of conveying of Garwood's boy to Bury and cutting him of the stone, which is still owing to them. Ordered that it be payd them again at or before Easter."

It appears from this extract that at that time there was no "stone cutter" in Norwich capable of performing the operation for the stone, and it was necessary to send the boy to Bury to be relieved of his disease. At that time there happened to be at Bury an expert lithotomist named Goodrick, for I find in the second volume of the Philosophical Transactions. 1667, the following note: "M Mr. Goodrick, surgeon, of Bury St. Edmunds, affirmed that himself cutting a lad of the stone (for which he has a great name), took out thence at one tirne 96 small stones."

"1655, 16 June.-Daniel Garrard's child in St. Margaret to be cut for the stone, and St. Peter Mancroft to make collection therefore."

This was a rather peremptory order to make for Peter to pay for St. Margaret's child.

" 1670,9 July.-It is ordered that papers be sent to ye ministers of St. Peter of Mancroft, St. Andrew, St. Lawrence, St. George of Tombland, and St. Stephens to exhort them their parishioners to contribute towards the charge of cuttinge the sonne of $\mathrm{Wm}$. Carr of the stone, and also towards the charge of the cure of Robert Hersfield of the same disease, which collection is to be made upon Sunday sen'night, and the money brought to ye court."

"The aldermen of ye Ward of West Wymer are desired to treat with Mr. Gutteridge the chyrurgeon about the cuttinge of William Carr his son."

Mr. Gutteridge was evidently a well-known lithotomist. His name occurs in connexion with the large stone taken after death from the bladder of Mrs. Kaisar of Bury, a blacksmith's wife. It weighed thirty-three ounces and a quarter, and was shown to Charles II. at Newmarket, and is now located in the museum at Cambridge. ${ }^{2}$

“ 1670, 11 Feb.-There was six pounds paid to $\mathrm{Mr}$. Ald Loikey for the cutting of Carr's boy in St. Margarets, and nine shillings and tenpence three farthings to Mr. Alderman Herne for one Samon of Pockthorpe afflicted with the stone out of the $£ 719 s .10_{4}^{3} \pi$. received of several parishes for ye cutting of two boyes of ye stone."

"1670, 3 Augt.- Mr. Swordbearer brought into ye court what money was collected for ye cuttinge of ye 2 boyes of ye stone-viz., in ye parish of St. Lawrence $25 s .5 d$.

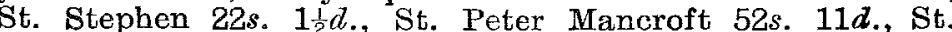
George Tombland 23s. $8 d$., St. Andrew $35 s .9 \frac{1}{4} d$., in all seven pounds, 19 shillings, and tenpence three farthings."

" 1670,3 Sep.-It is ordered (if ye Lord Bishop of Norwich shall assent thereto) that a collection be made for Thomas Tuck, the son of Law Tuck of St. Fdmund, in all the parishes in the wards beyond the water towards ye charge of cutting him of ye stonne."

"1670, 4 Sep. $-50 s$. to be paid to Law Tuck for the cutting his son Thomas of the stonne."

Were Mr. Gutteridge and Mr. Goodrick the same person? Probably Mr. Goodrick, finding there was no lithotomist in Norwich, migrated to that city, and either changed his name or the scriveners did so for
him. 
"1671, 26 Aug.-It is desired that the Ald of West Wymer ward doe weight upon the Bishopp to desire his Lordship to recommend ye afflicted condition of a child of Martin Baxter in St. Margaret's who is troubled with the stone, to ye ministers of St. Lawrence, St. Peter Mancroft, St. Gregories, St. Andrew and St. George, Tombland, to encite their pshoners [parishioners] to a voluntary contribution to the cutting him of the stone."

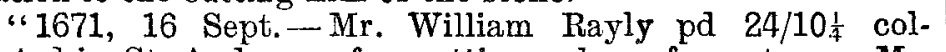
lected in St. Andrewes for cutting a boy of ye stone. Mr. Manninge pd 23/9d. collected in St. Gregories upon that account which two sums were paid to ye swordbearer. $\mathrm{Mem}$. there was formerly pd to $\mathrm{Mr}$. Swordbearer $50 \mathrm{~s}$. of St. George Tombland and 20s. of St. Peter Mancroft and of Laurence 13s."

" 1671, 3 Dec.-That Charles Brook have leave to collect the charity of such persons as will contribute towards the charge of cuttinge his chyld of the stonne."

"1672. 22 May. - Mr. Maior pd out of the hamper [hanaper] 5s. to $\mathrm{Mr}$. Alderman Herne towards the cure of Wm. Anger's child of the stone and that ye person that undertake ye cure shall have 10s. pd out of ye hamper when ye cure is done."

" $1673,4 \mathrm{Fe}$. - It is agreed that Mr. Guttridge shall hare $£ 5$ pd. him u pon the cuttinge of $\mathrm{Wm}$. Angus's child of ye stone, if the stone be produced in ys court notwithstandinge ye child shall dye by reason of the cuttinge."

"1674, 15 Apri1.- It is agreed that applications be made by Ald Rich Wenman and Ald Crow to ye Lord Bishop for his lycence to hare a collection in ye parishes of St. Gyles, St. Peter of Mancroft, and St. Stephen towards the charge of cut'ing ' $h$ : sonne of - Brooke of St. Gyles of the stonne."

“1674, 2 May.-This day Mr. Maior pd.20s. to Wm. Angus's wife of St. James towards the cuttinge of his chyld of the stonne and providinge of lynnen and other things."

"1674, 9 May.-Churchwardens and overseers of all ye parishes in the great ward beyond ye water desired to goe from house to house to receive ye charity of such as will contribute to the chardge of cuttinge ye sonne of Wm. Angus of St. James of the stone."

" 1674, 20 May.-Jt is ordered that Robert Wegg a poore boy in the boyes hospi a'l of the nomination of the towne of Saxthorpe and of the benefaction of Mr. Vaughan being very much afflicted with ye stonne in his bladder be (as is desired Wy the inhabitants of Saxthorpe mentioned in a letter from Jo Raye, Esa.) cut of the stone by Mr. Guteridge, the charge whereof and of a keeper is to be defrayd at ye public charge and that collection be made to ye purpose."

"1674, 30 May-It is agreed that Mr. Ald Wrench sball be reimbursed $5 l$, which he shall disburse for the cuttinge of the stonne of ye sonne of Thos. Sharpin of St. Paul out of the monies shall be collected in the severall parishes of the city for cuttinge of several poore children of the stonne."

" 1674, 11 July.--Hen Herne, Esq., and Mr. Ald Wrench are desired by this court to attend ye Ld. Bp. of Norwich and pray his allowance for the several ministers of this city to encite their congregationes to a free and charitable contribution towards the severall persons whose chardge hath been greate for to be cut of ye stonne, which contribution is to be gathered by ye officers of ye respective parishes by going from house to house to receive the sd. charity and not to be collected in the churches."

" 1674,24 Augt. - It is ordered that Mr. Swordbearer doe pay unto Henrie Herne, Esq. £5 (out of the money in his hands collected for cutting persons of the stone) for so much by him disbursed for cuttinge Angus's boy of ye stonne."

"1675, $25 \mathrm{Feb}$-It is agreed that young Mr. Gutridge shall have $40 \mathrm{~s}$. for the insisicion or extraction of a stone out of the gland of the penis of John Johnson of St. John Sepulcher."

" 1675,2 Oct. - It is agreed that there be a collection (if the Ld. Bp. shall assent thereto) made towards the charge of cuttinge the sonne of Jo Sullman, of the parish of St. Stephen, of the stone, in the parishes of St. Stephen, St. Peter Mancroft, St. James, St. Michael Costany, and St. George Tombland, and which money be collected to be brought up to ye courts."

" 1677, 9 Jany.-Collection to be made for cutting of the stone of two poor bodres of St. Martin Palace and St. Michael-at-Thorn."

"1678, 4 Sep.-The scnne of Samnel Joy of St. George Colgate, 4 years and $\frac{1}{2}$ old and much afflicted with ye stonne, is recommended to the charitie of this court and others to have ye charge of cutting him defrayed, and $\mathrm{Mr}$. Guttridge was discoursed about it and contracted with for $£ 4$ to be raised by contribution."

1680, 18 August.-Application to be made to ye Ld. Bp. of Norwich for license to collect ye charity of good Christians towards ye charge of cutting of Jo Wharton and also of Philip Thurton."

"1681, 4 June.-That Robert Bendish, Esq., and Mr Town Clerk doe addresse ye Ld. Bp of Norwich for his license to make a collection in the severall parishes of St. Peter Man., St. Stephen, St. Giles, St. George Timberhill, St. Andrew; and St. Clement for Jo Fitts to be cutt of ye stonne."

"1682, $5 \mathrm{July}$.-A petition read from Nich Stocking of St. Peter Mancroft that one of his six children is greviously afflicted with ye stone in his bladder, and the said Stocking poore and unable to bear the charge of his cutting and cure. Ald Gardiner and Mr. Town Clerk to attend Rt. Rev. Anthony Sparrow, Lord Bishop of Norwich, to ask leave for a collection at the next and following Lord's daies."

" $1682,26 \mathrm{July}$. - It is ordered that what monie remaining of ye monie collected for ye cutting of ye sonne of Nich Stocking of ye stonne (Mr. Gutteridge being paid) and ye chylde being dead since cuttinge, be paid by ye swordbearer to ye parents."

In addition to the above I find an entry in the register of St. Peter Mancroft unäer the date 1703:-- "Received by $a_{\text {n }}$ collection for a person cutt of the stone 010405 ," and "paid the swordbearer the money for cutting the person of the stone." This extract is interesting as it proves that church collections were made to the year 1703 , but probably not much beyond that time, inasmuch as in 1711 a court of guardians was incorporated by Act of Parliament to erect workhouses and regulate the maintenance of the poor of Norwich. The method that had been adopted for so many years was therefore abandoned, and all cases of stone and other diseases were brought under the powers of the Poorlaw Act.

\section{INFIRMARY NURSING AND THE NEW SUPERANNUATION ACT.}

We published last week a letter from the chairman of the committee which was mainly instrumental in securing the passing of the Poor-law Officers' Superannuation Act in reference to its bearing on nurses and female servants in that service. Mr. Rutherglen is a gentleman of very great experience in the Poor-law, and his authority in. matters of Poor-law is sure to be recognised. But when he approaches the subject of nursing he seems to be not quite so much at home. He argues that the deduction from a nurse's or probationer's salary would not be a deterrent to high-principled young women who join the service with a sense of devotion to duty Our correspondent forgets that though this high principle may be a motive in some cases, in most instances the object is to earn a living, sometimes for others as well as for themselves. It is this which far more often induces young women to join a none too attractive service and one none too valuable for purposes of education. and experience. Moreover, even if it were as he states. it would not be justice to trade, as it were, on the high. principle of others, and make them contribute to a fund from which they are never likely to receive any benefit, because nine-tenths or more of them only take up workhouse or infirmary duties for a few years by way of experience. They have soon learned all they can in this class of work, and know, as others know also, that if they stay long they contract leisurely habits by reason of the ennui and monotony of the life. The best matrons maintain that an period of three or four years is ample for a nurse to stay at an infirmary both in the interests of the nurse herself and in the cause of good nursing. After that time she gets into a set groove and develops an inclination to depute to the semi-able-bodied persons around her work which she. ought to do herself. The new Act, it seems to us, would induce her to stay on indefinitely.

However, that the small deduction would prove a deterrent. from entering the service is the least of its objections, though the pay is none too liberal, and consequently the supply of good nurses for the service none too plentiful. 